\title{
Oxidative Stress in Patients with Chronic Hepatitis B and C
}

\author{
Pınar Çıragil1', Ergül Belge Kurutaş², Ömer Faruk Kökoğlu³ ${ }^{3}$, Murat Aral ${ }^{4}$ \\ ${ }^{1}$ Department of Microbiology and Clinical Microbiology, BSK Metropark Hospital, Adana, Turkey \\ ${ }^{2}$ Department of Biochemistry, Faculty of Medicine, Kahramanmaraş Sütçü Imam University, Kahramanmaraş, Turkey \\ ${ }^{3}$ Department of Infectious Diseases, Faculty of Medicine, Kahramanmaraş Sütçü Imam University, Kahramanmaraş, Turkey \\ ${ }^{4}$ Department of Microbiology and Clinical Microbiology, Faculty of Medicine, Kahramanmaraş Sütçü Imam University, \\ Kahramanmaraş, Turkey
}

\begin{abstract} patients with chronic hepatitis $B(\mathrm{CHB})$ and $\mathrm{C}(\mathrm{CHC})$. should be useful for these patients.

Key Words: HBV, HCV, antioxidant enzymes, malondialdehyde

Received: 05.03.2010 Accepted: 28.05.2010
\end{abstract}

Objective: Hepatitis $B$ and hepatitis $C$ virus infections are extensively seen throughout the world. Disturbances in the antioxidant system and oxidative stress may play a role in the pathogenesis of chronic liver diseases. The aim of this study was to evaluate the oxidant/antioxidant status in the serum of

Material and Methods: Twenty patients with $\mathrm{CHB}, 20$ with $\mathrm{CHC}$ and 30 healthy volunteers were included in this study. Catalase (CAT), superoxide dismutase (SOD) activities and malondialdehyde (MDA) levels were measured in all patients and control group specthrophotometrically.

Results: While CAT and SOD activities were significantly lower in patients with $\mathrm{CHC}$, these enzymes were significantly higher in patients with $\mathrm{CHB}$ compared to controls. However, MDA levels were increased in each patient group as compared to the control group. Also, antioxidant enzyme activities were found to be significantly lower and MDA levels were higher in patients with $\mathrm{CHC}$, compared to patients with CHB.

Conclusion: We considered that insufficiency of antioxidant barrier may cause oxidative stress in patients with $\mathrm{CHB}$ and $\mathrm{CHC}$, so antioxidant treatment

\section{Introduction}

Hepatitis $\mathrm{C}$ virus $(\mathrm{HCV})$ is the main causative agent of chronic viral hepatitis and hepatitis $B$ virus (HBV), extensively seen throughout the world, can become highly chronic. However, the pathogenesis of chronic hepatitis is not yet fullyknown. Although the liver is well endowed with endogenous enzymatic antioxidants, it also has active microsomal and mitochondrial systems that generate reactive oxygen species (ROS) during normal metabolic processes $(1,2)$. Oxidative stress develops when a disturbance in balance between ROS produced in excess and factors preventing their harmful effects occurs. To prevent destruction caused by oxidative stress, the host uses the antioxidant defence enzymes such as superoxide dismutase (SOD) and catalase (CAT) (3). ROS damage cell proteins and nucleic acids, and trigger the lipid peroxidation process. It has been reported that lipid peroxidation is one of the reasons for hepatocyte damage and also increases the level of malondialdehyde (MDA) which is a biomarker of oxidative stress (4).

There are some studies about the oxidative stress in chronic hepatitis B or hepatitis C patients (5-9). De Maria et al. (10) showed that MDA, a product of polyunsaturated fatty acid peroxidation, was elevated in the liver and blood. Paradis et al. (11) also demonstrated MDA-protein adducts immunohistochemically in infected liver tissue. Boya et al. (9) showed that the peripheral blood mononuclear cells from patients with chronic hepatitis $C$ had increased MDA concentrations, and enhanced SOD activity. Romero et al. (12) showed higher serum MDA values in chronic hepatitis $C$ patients than healthy subjects before the interferon treatment.

The present study evaluates the existence of oxidative stress in serum of patients with chronic hepatitis $\mathrm{B}(\mathrm{CHB})$ and chronic hepatitis $\mathrm{C}(\mathrm{CHC})$ and questions whether disturbances in antioxidant balance are present in these cases. Also the question of whether there were differences between hepatitis $B$ and hepatitis $C$ patients of antioxidant enzymes and oxidative stres was investigated.

\section{Material and Methods}

\section{Patient and Control Group}

The study was carried out in 40 patients aged $24-43$ years, 20 of these had $\mathrm{CHB}, 20$ had $\mathrm{CHC}$ and 30 healthy voluntary people did not have HBV, HCV infection or etiologic causes which give rise to chronic liver disease. Smokers, alcohol consumers, those having chronic diseases other than liver diseases (chronic obstructive lung disease, diabetes, etc.), and subjects using antioxidant vitamin, fish-oil or iron supplements and any drug that may affect free radicals (beta blockers etc.) 
were excluded from the study. In the diagnosis of $\mathrm{CHB}, \mathrm{HBsAg}$ positivity lasting more than 6 months, anti-HBc lgG, $\mathrm{HBeAg}$ and/or anti- HBeAg and HBV-DNA (PCR) positivity, were taken as criteria. Also in the diagnosis of $\mathrm{CHC}$, anti-HCV positivity lasting more than 6 months and HCV-RNA (PCR) positivity were taken as criteria. Antigens and antibodies were analyzed with the ELISA (Abbott-axsym, USA) system. HBV-DNA and HCV-RNA were investigated with $600 \mathrm{copy} / \mathrm{ml}$ sensitivity with "reverse transcription (RT)-PCR (Cobas Amplicor Monitor; Roche Brenchburg, New Jersey, USA).

The study was carried out according to the Guidelines of the Local Ethic Committee of the Faculty of Medicine, Kahramanmaras Sutcu Imam University.

Venous blood samples were taken from the patients and control groups, and sera were separated from the cells by centrifugation and analysed for biochemical analysis.

\section{Biochemical Analysis}

In all biochemical analysis, analytical grade products of Merck (Darmstald, Germany) were used.

\section{Assay of SOD Activity}

SOD activity was measured according to the method described by Fridovich (13). This method employs xanthine and xanthine oxidase to generate superoxide radicals, which react with $\mathrm{p}$-iodonitrotetrazolium violet (INT) to form a red formazan dye which was measured at $505 \mathrm{~nm}$. Assay medium consisted of the $0.01 \mathrm{M}$ phosphate buffer, 3-cyclohexilamino1-propanesulfonicacid (CAPS), buffer solution (50 mM CAPS, $0.94 \mathrm{mM}$ EDTA, saturated $\mathrm{NaOH}$ ) with $\mathrm{pH} 10.2$, solution of substrate (0.05 mM xanthine, $0.025 \mathrm{mM}$ INT) and $80 \mathrm{U} / \mathrm{L}$ xanthine oxidase. SOD activity in serum samples was expressed as $\mathrm{U} / \mathrm{mg}$ protein.

\section{Assay of CAT activity}

CAT activities were determined by measuring the decrease in hydrogen peroxide concentration at $230 \mathrm{~nm}$ by the method of Beutler (14). Assay medium consisted of $1 \mathrm{M}$ Tris $\mathrm{HCl}, 5 \mathrm{mM}$ $\mathrm{Na}_{2}$ EDTA buffer solution ( $\mathrm{pH} 8.0$ ), $1 \mathrm{M}$ phosphate buffer solution ( $\mathrm{pH}$ 7.0), and $10 \mathrm{mM}$ hydrogen peroxide. CAT activity in serum samples was expressed as $\mathrm{U} / \mathrm{mg}$ protein.

\section{Assay of MDA level}

Lipid peroxidation level in the serum samples was expressed by MDA. It was measured according to the procedure of Ohkawa et al. (15). The reaction mixture contained $0.1 \mathrm{~mL}$ sample, $0.2 \mathrm{~mL}$ of $8.1 \%$ sodium dodecyl sulphate, 1.5 $\mathrm{mL}$ of $20 \%$ acetic acid and $1.5 \mathrm{~mL}$ of $0.8 \%$ aqueous solution of thiobarbituric acid. The mixture $\mathrm{pH}$ was adjusted to 3.5 and the volume was finally made up to $4.0 \mathrm{~mL}$ with distilled water, and $5.0 \mathrm{~mL}$ of the mixture of $\mathrm{n}$-butanol and pyridine $(15: 1, \mathrm{v} / \mathrm{v})$ were added. The mixture was shaken vigorously. After centrifugation at $4000 \mathrm{rpm}$ for $10 \mathrm{~min}$, the absorbance of the organic layer was measured at $532 \mathrm{~nm}$.

\section{Assay of protein level}

The protein concentration of the serum samples were measured by Shimadzu UV-200 (Japan) spectrophotometer by the method of Lowry (16).

\section{Statistical analysis}

In the statistical evaluation of the data, the SPSS 13.0 Windows program was used. Comparison of the groups was carried out through Mann-Whitney $U$ test analysis.

\section{Results}

In CHB patients, CAT and SOD activities and MDA levels found were significantly higher compared to the control group $(p<0.001)$, as shown in the table. However, MDA levels of patients with $\mathrm{CHC}$ were significantly higher, CAT and SOD activities were significantly lower than the control group and the patients with $\mathrm{CHB}(\mathrm{p}<0.001)$, as shown in the table.

Furthermore, elevated CAT and SOD activities were found in $\mathrm{CHB}$ patients compared to $\mathrm{CHC}$ patients $(\mathrm{p}<0.001)$. On the other hand, while increased MDA levels were found in $\mathrm{CHC}$ patients, it was decreased in $\mathrm{CHB}$ patients $(\mathrm{p}<0.001)$. Results were shown in Table 1, Figure 1, Figure 2 and Figure 3.

\section{Discussion}

Some of the ROS which have useful physiological functions are produced continuously in the human organism, but they may be threatening for normal cell function and integrity when produced in excess. Consequently, aerobic organisms developed defence mechanisms, such as CAT and SOD

Table 1. Catalase and superoxide dismutase activities and malondialdehlde levels in the patients and control group

\begin{tabular}{|c|c|c|c|c|c|}
\hline & $\begin{array}{l}\text { Control } \\
\text { Group }\end{array}$ & HBV & $\mathrm{HCV}$ & $p^{*}$ & $p^{\star *}$ \\
\hline $\begin{array}{l}\text { CAT } \\
\text { (U/mg } \\
\text { protein) }\end{array}$ & $2.33 \pm 0.50$ & $3.20 \pm 0.58$ & $1.79 \pm 0.37$ & $<0.001$ & $<0.001$ \\
\hline $\begin{array}{l}\text { SOD } \\
\text { (U/mg } \\
\text { protein) }\end{array}$ & $31.5 \pm 0.53$ & $4.95 \pm 0.59$ & $2.60 \pm 0.47$ & $<0.001$ & $<0.001$ \\
\hline $\begin{array}{l}\text { MDA } \\
(\mathrm{nmol} / \mathrm{ml})\end{array}$ & $2.20 \pm 0.28$ & $2.98 \pm 0.37$ & $3.87 \pm 0.52$ & $<0.001$ & $<0.001$ \\
\hline \multicolumn{6}{|c|}{$\begin{array}{l}\text { *Significant differences between chronic hepatitis B and C patients avnd control } \\
\text { groups } \\
{ }^{*} \text { Significant differences between chronic hepatitis B and C patients }\end{array}$} \\
\hline
\end{tabular}

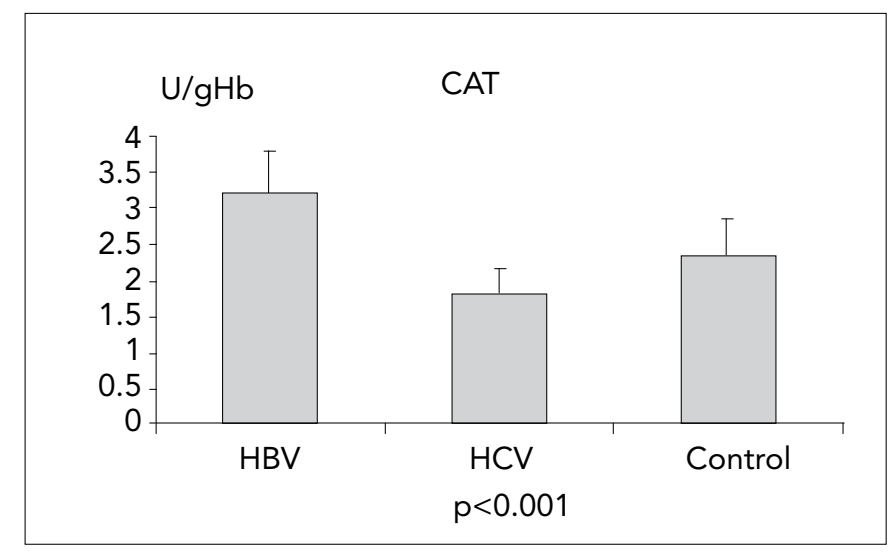

Figure 1. Catalase activities in the patients and control group 


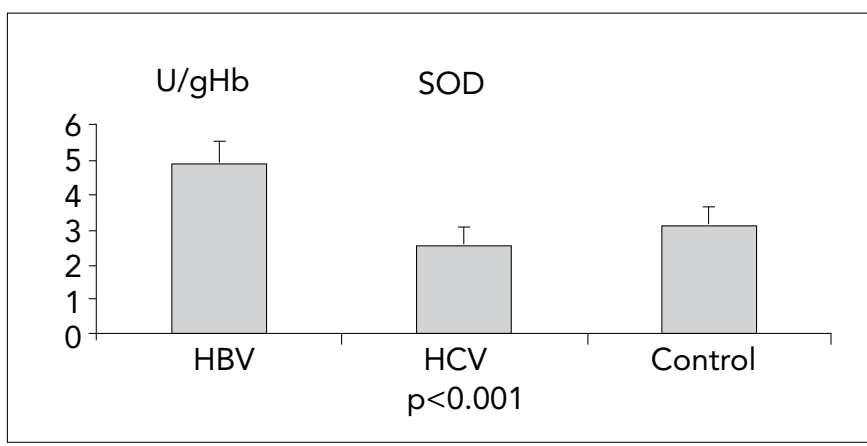

Figure 2. Superoxide dismutase activities in the patients and control group

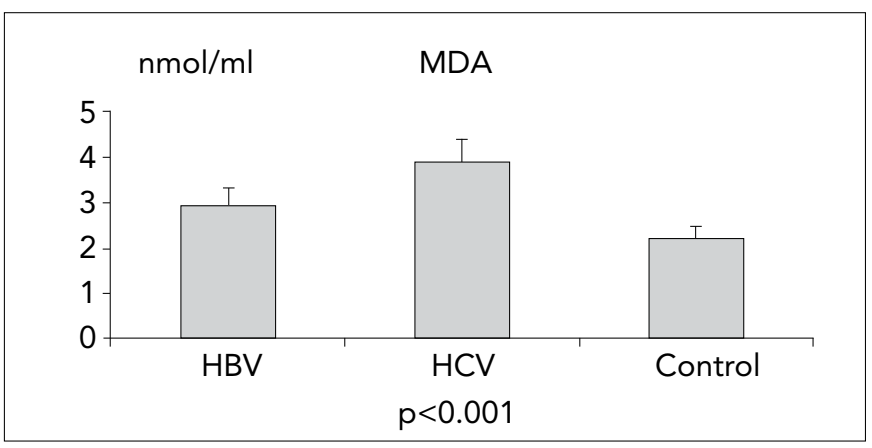

Figure 3. Malondialdehyde levels in the patients and control group

against the harmful effects of ROS. The reports from several studies have produced evidence that a good correlation existsbetween type and severity of disease and antioxidant level in blood, such as cardiovascular diseases, neurological diseases, pulmoner diseases etc. In the present study we have determined antioxidant enzyme activities and MDA levels in patients with $\mathrm{CHB}$ and $\mathrm{CHC}$.

We demonstrated that CAT and SOD activities were increased in patients with $\mathrm{CHB}$, so there may be a response to oxidative stress in patients with $\mathrm{CHB}$. On the other hand, the capacities of antioxidant enzymes were decreased in patients with $\mathrm{CHC}$; thereby we thought that there may be oxidative damage in these patients.

When the activities of these antioxidant enzymes are inadequate, the organism is not capable of neutralizing excessive ROS, and a hepatocyte lesion occurs as a consequence. In the present study we found that CAT and SOD activities were lower in $\mathrm{CHC}$ compared to $\mathrm{CHB}$. Demirdag et al.(8) reported that CAT and SOD activities were significantly lower in patients with chronic hepatitis $B$ and $C$, than the control group. The results of our study are similar to these reports. Irshad et al.(6) studied the activity of SOD and total antioxidants in patients with various forms of liver diseases caused by hepatitis virus. They reported that SOD level was significantly reduced in all patients irrespective of the viral etiology.

In our study serum MDA levels of patients with $\mathrm{CHB}$ and $\mathrm{CHC}$ were found to be significantly higher compared to the control group. We also determined that this parameter in patients with $\mathrm{CHC}$ was significantly higher than in $\mathrm{CHB}$ patients. In liver damage caused by viral etiology, it is reported that the MDA level in serum and liver tissue increases. Nagoev et al. (17) demonstrated that serum MDA level was increased in patients with hepatitis $B$ and hepatitis $C$, at the peak of the disease, during regression and during early convalescence. MDA is the final product of lipid peroxidation and it has been reported that lipid peroxidation is one of the reasons for hepatocyte damage. In our study, we thought that the higher MDA levels than the control group indicates the existence of oxidative stress in all chronic hepatitis $B$ patients. We also found that MDA levels in $\mathrm{CHC}$ patients were higher than $\mathrm{CHB}$ patients. Elevated MDA levels and decreased antioxidant enzyme activities in patients with $\mathrm{CHC}$ may indicate an oxidative damage. The results presented confirm the involvement of oxidative stress as part of the pathophysiology of $\mathrm{CHC}$. Thus, our findings support the existence of the oxidative stress in patients with chronic HCV or HBV infection and are in agreement with the studies mentioned above.

\section{Conclusion}

According to the results of this study, it might be thought that serum MDA level could be a marker of hepatocellular damage in $\mathrm{CHB}$ and $\mathrm{CHC}$ patients. Also ROS take part in the pathogenesis of chronic hepatitis $C$ as they decrease antioxidant enzymes activities. Therefore we consider that, in the treatment of chronic hepatitis $B$ and $C$, antioxidant treatment may useful and should be added to combined therapy for these patients.

\section{Conflict of Interest}

No conflict of interest was declared by the authors.

\section{References}

1. Robinson WS. Hepatitis B virus and Hepatitis D virus. In: Mande $\mathrm{GL}$, Bennett JE, Dolin R, editors. Principles and Practice of Infectious Diseases. 5th ed. New York: Churchill Livingston; 2000. pp. 1652-84.

2. Thomas DL, Lemon SM. Hepatitis C. In: Mandel GL, Bennett JE, Dolin R, editors. Principles and Practice of Infectious Diseases. 5th ed. New York: Churchill Livingston; 2000. pp. 1736-59.

3. Sies H. Strategies of antioxidant defences. Eur J Biochem 1993;215:213-9. [CrossRef]

4. Rosser BG, Gores GJ. Liver cell necrosis: cellular mechanisms and clinical implications. Special reports and reviews. Gastroenterology 1995;108:252-75. [CrossRef]

5. Broide E, Klinowski E, Koukoulis G, Hadzic N, Portmann B, Baker $A$, et al. Superoxide dismutase activity in children with chronic liver diseases. J Hepathol 2000;32:188-92. [CrossRef]

6. Irshad M, Chaudhuri PS, Joshi YK. Superoxide dismutase and total antioxidant levels in various forms of liver diseases. Hepatology Research 2002;23:178-84. [CrossRef]

7. Chrobot AM, Szaflarska-Szczepanik A, Drewa G. Antioxidant defence in children with chronic viral hepatitis B and C. Med Sci Monit 2000;6:713-8.

8. Demirdag K, Yilmaz S, Ozdarendeli A, Ozden M, Kalkan A, Kilic SS. Levels of plasma malondialdehyde and erythrocyte antioxidant enzyme activities in patients with chronic hepatitis B. Hepatogastroenterology 2003;50:766-70. [CrossRef]

9. Boya P, de la Peña A, Beloqui O, Larrea E, Conchillo M, Castelruiz $Y$, et al. Antioxidant status and glutathione metabolism in periph- 
eral blood mononuclear cells from patients with chronic hepatitis C. J Hepatol 1999;31:808-14. [CrossRef]

10. De Maria N, Colantoni A, Fagiuoli S, Liu G-J, Rogers BK, Farinati $F$, et al. Association between reactive oxygen species and diseaseactivity in chronic hepatitis C. Free Radic Biol Med 1996;21:291-5. [CrossRef]

11. Paradis $V$, Mathurin $P$, Kollinger $M$, Imbert-Bismut $F$, Charlotte F,Piton A, et al. In situ detection of lipid peroxidation in chronic hepatitis C:correlation with pathological features. J Clin Pathol 1997;50:401-6. [CrossRef]

12. Romero MJ, Bosch-Morell F, Romero B, Rodrigo JM, Sera MA, Romero FJ. Serum Malondialdehyde: Possible use for the clinical management of chronic hepatitis $\mathrm{C}$ patients. Free Radic Biol Med 1998;25:993-7. [CrossRef]
13. Fridovich I. Superoxide radical: an endogenous toxicant. Annu Rev Pharmacol Toxicol 1983;23:239-57. [CrossRef]

14. Beutler E. Red: Cell Metabolism. Grune and Stratton Company, New York 1975;261-5. [CrossRef]

15. Ohkawa H, Ohishi N, Tagi K. Assay for lipid peroxides in animal tissues by thiobarbituric acid reaction. Anal Biochem 1979;95:351-8. [CrossRef]

16. Lowry O, Rosebrough NJ, Farr AL, Randall RJ. Protein measurement with the folin phenol reagent. J Biochem Chem 1951;193:265-75.

17. Nagoev BS, Abidov MT, Ivanova MR. LPO and free radical oxidation parameters in patients with acute viral hepatitis. Bull Exp Biol Med 2002;134:557-8. [CrossRef] 